\title{
PERSONAL BRANDING DALAM KOMUNIKASI SELEBRITIS (STUDI KASUS PERSONAL BRANDING ALUMNI ABANG NONE JAKARTA DI MEDIA SOSIAL "INSTAGRAM")
}

\author{
Ievansyah ${ }^{1)}$ dan Teguh Priyo Sadono ${ }^{2)}$ \\ 1) Magister IImu Komunikasi, Universitas Bunda Mulia \\ 2) Magister IImu Komunikasi, Universitas Bunda Mulia
}

Disetujui 14 Agustus 2018

\begin{abstract}
Abang None is a designation for Jakarta Tourism Ambassador. Researchers saw a phenomenon of self-transformation from a tourism ambassador to a celebrity. This phenomenon refers to case studies experienced by Maudy Koesnaedi, Bangpen, and Shabina Gianti. Researchers want to know the personal branding management process they want to form, and convey it to the public through Instagram social media. This study uses qualitative methods, with descriptive case studies, which depart from the Post Positivism paradigm. The concept used is personal branding, and is sharpened by the theory of Communication Private Management (CPM Theory). Data collection techniques are observation, interviews, and documentation analysis. The concept of personal branding proposed by Peter Montoya, refers to eight laws, namely the law of specialization, the law of leadership, the law of personality, the law of distinctiveness. , the law of appearance (the law of visibility), the law of unity, the law of persistence, and the law of good intentions. From these eight laws, the researcher saw that the three sources had different features, were consistent in managing personal branding, and were able to demonstrate good ethics in using social media. The theory of Communication Private Management (CPM Theory), proposed by Sandra Petronio, has five basic assumptions to see how they manage personal information in the public domain. The five assumptions are private information, private boundaries, control and ownership, rule-based management systems, and management dialectics. The three informants in general have known the limitations of their privacy with the public, so they understand the information that is allowed and not to be shared with the public. They have good management, between them and netizens. Researchers hope that further research can further develop the concept of personal branding, and CPM theory. Hopefully this research can be a reference, to be better developed from all aspects.
\end{abstract}

Keywords: Personal Branding, Abang None, Celebrity, Instagram

\begin{abstract}
ABSTRAK
Abang None merupakan sebutan untuk Duta Pariwisata DKI Jakarta. Peneliti melihat adanya fenomena transformasi diri dari duta pariwisata menjadi seorang selebritis. Fenomena ini mengacu pada studi kasus yang dialami oleh Maudy Koesnaedi, Bangpen, dan Shabina Gianti. Peneliti ingin mengetahui proses pengelolaan personal branding yang ingin mereka bentuk, dan sampaikan ke publik lewat media sosial Instagram. Penelitian ini menggunakan metode kualitatif, dengan studi kasus deskriptif, yang berangkat dari paradigma Post Positivisme. Konsep yang digunakan adalah personal branding, dan dipertajam dengan teori Communication Private Management (CPM Theory). Teknik pengumpulan datanya ialah observasi, wawancara, dan analisis dokumentasi. Konsep personal branding yang dikemukakan oleh Peter Montoya, mengacu pada delapan hukum, yaitu hukum spesialisasi (the law of specialization), hukum kepemimpinan (the law of leadership), hukum kepribadian (the law of personality), hukum perbedaan (the law of distinctiveness), hukum kenampakan (the law of visibility), hukum kesatuan (the law of unity), hukum keteguhan (the law of persistence), dan hukum maksud baik (the law of good will). Dari kedelapan hukum ini, peneliti melihat bahwa ketiga narsumber memiliki
\end{abstract}


keistimewaan yang berbeda-beda, konsisten dalam mengelola personal branding, dan mampu menunjukkan etika yang baik dalam sosial. Teori Communication Private Management (CPM Theory), yang dikemukakan oleh Sandra Petronio, memiliki lima asumsi dasar untuk melihat bagaimana mereka mengelola informasi yang bersifat pribadi di wilayah publik. Lima asumsi itu ialah informasi privat, batasan privat, kontrol dan kepemilikan, sistem manajemen berdasarkan aturan, dan dialektika manajemen. Ketiga narasumber secara garis besar sudah mengetahui batasan privasi mereka dengan publik, sehingga mereka memahami informasi yang boleh dan tidak untuk dibagikan kepada publik. Mereka memiliki manajemen yang baik, antara mereka dan netizen. Peneliti berharap semoga penelitian selanjutnya bisa lebih mengembangkan konsep personal branding, dan teori CPM. Semoga penelitian ini bisa menjadi rujukan, untuk dikembangkan lebih baik lagi dari segala aspek.

Kata Kunci: Personal Branding, Abang None, Selebritis, Instagram

\section{PENDAHULUAN}

\section{Latar Belakang Penelitian}

Dalam penelitian ini, peneliti melihat bahwa tidak sedikit para finalis Abang None Jakarta yang ketika selesai menjabat sebagai duta pariwisata, melanjutkan kompetensi dirinya ke arah industri hiburan yaitu menjadi selebritis. Hal ini mengacu pada studi kasus yang dialami oleh ketiga objek penelitian yaitu Maudy Koesnaidi, Bangpen, dan Shabina Gianti. Dari ketiga objek penelitian ini, peneliti akan mencoba memaparkan realitasnya dari yang pertama yaitu Maudy Koesnaidi (Mpok Mod). Mpok mod berhasil terpilih menjadi None Jakarta 1993. Selepas menjadi Abnon, ia mencoba kemampuan aktingnya lewat film "Si Doel Anak Sekolahan", yang mana dari film itu ia sukses menjadi seorang selebritis yang dikagumi banyak orang hingga saat ini. Kedua ada Fendi (Bangpen), yang terpilih sebagai wakil 1 Abang Jakarta Utara tahun 2014. Selepas menjadi Abnon, ia yang gemar komedi ini mencoba kemampuan humornya di media sosial Instagram, yang sukses membuatnya dikagumi banyak penggemar, dan beberapa kali diundang untuk bergabung di acara TV nasional. Ketiga ada Shabina Gianti (Shabi), yang terpilih sebagai finalis None Jakarta Utara tahun 2016. Selepas menjadi Abnon, ia yang amat tertarik dengan dunia tari dan sandiwara, mencoba peruntungan di industri TV nasional. Hasilnya ia sukses

\footnotetext{
*Korespondensi Penulis:

E-mail: ievansyah_93@yahoo.com
}

mendapatkan peran dalam acara komedi OK-JEK di NET TV.

Peneliti melihat adanya fenomena transformasi diri dari duta pariwisata menjadi seorang selebritis. Hal ini lah yang mendorong ketertarikan peneliti untuk melakukan penelitian, khususnya dalam studi personal branding. Untuk itu penelitian ini akan berbicara mengenai personal branding, dengan tujuan untuk mencari tahu bagaimana usaha mereka dalam mewujudkan personal branding yang mereka inginkan, dan bagaimana mereka mengkomunikasikannya ke lingkungan sosialnya. Dengan hadirnya teknologi web 2.0 , media sosial memiliki peran signifikan dalam konteks komunikasi pemasaran personal, dimana selebriti menggunakan media sosial sebagai sarana personal branding. Untuk itu penelitian ini juga akan membahas mengenai peranan media sosial yang mereka miliki dalam menunjang proses personal branding mereka.

\section{Rumusan Penelitian dan Identifikasi Penelitian}

Berdasarkan latar belakang penelitian yang telah peneliti terangkan pada sub-bab sebelumnya, maka rumusan penelitian ini adalah personal branding dalam komunikasi selebritis pada alumni Abang None Jakarta. Adapun yang menjadi identifikasi penelitian dalam penelitian ini adalah sebagai berikut:

1) Bagaimana para alumni Abnon sebagai selebritis mengelola personal branding mereka di media sosial instagram? 
2) Kenapa para alumni Abnon sebagai selebritis melakukan manajemen privasi di wilayah publik?

\section{Maksud dan Tujuan Penelitian}

Berdasarkan rumusan penelitian dan identifikasi penelitian yang telah peneliti uraikan di atas, maka maksud dari penelitian ini adalah untuk menganalisis personal branding dalam komunikasi selebritis pada alumni Abang None Jakarta. Adapun tujuan diadakannya penelitian ini adalah sebagai berikut:

1) Menjelaskan proses pengelolaan personal branding para alumni Abnon sebagai selebritis di media sosial instagram.

2) Mengetahui tujuan para alumni Abnon sebagai selebritis melakukan manajemen privasi di wilayah publik.

\section{Kegunaan Penelitian}

Peneliti meyakini jika penelitian ini dikelola dengan baik, maka penelitian ini akan menghasilkan signifikansi baik itu signifikansi teoritis atau akademis, maupun praktis. Selanjutnya peneliti akan menjelaskan kedua signifikansi ini, sebagai berikut.

- Aspek

Akademis

Penelitian ini diharapkan dapat memperkaya kajian teoritis ilmu komunikasi pada bidang komunikasi selebritis, khususnya teori dan pemahaman mengenai personal marketing communicatoin, dimana terdapat tahap-tahap yang dialami oleh seseorang sebelum ia menemukan personal branding yang diinginkannya.

- Aspek

Praktis

Dari aspek praktis ini, peneliti mengharapkan hasil penelitian ini dapat memberikan manfaat pengetahuan bagi para alumni Abang None Jakarta lainnya sehingga mereka mampu untuk menemukan apa sesungguhnya personal branding yang mereka ingin capai, dan menerapkannya dalam dunia kerja.
Selain itu, peneliti juga berharap agar penelitian bisa menjadi rujukan refrensi bagi para peneliti lainnya yang memiliki penelitian sejenis.

\section{TINJAUAN PUSTAKA}

\section{Review Hasil Penelitian Sejenis}

Dalam penelitian ini, peneliti mengangkat topik mengenai personal branding, namun peneliti memiliki keunikan tersendiri dalam penelitian ini. Bila melihat dari penelitian terdahulu, para penelitinya terpaku oleh konsep dari personal branding itu saja. Disini peneliti melihatnya secara lebih luas. Peneliti memadukan konsep personal branding dengan teori tambahan yaitu teori motivasi (Abraham Maslow), dan teori utamanya yaitu teori manajemen privasi komunikasi (CPM Theory).

Ini merupakan teori yang berbicara mengenai bagaimana seseorang mengelola informasi tentang dirinya di lingkungan sosial. Sebuah teori yang digunakan untuk mengungkap karakter seseorang yang memilih menjadi pribadi yang terbuka atau sangat menjaga privasi. Teori ini peneliti anggap penting, mengingat ketiga subjek penelitian ini merupakan selebritis yang kehidupannya sangat menjadi sorotan publik. Hal ini sekaligus menambah keunikan itu sendiri, karena belum ada penelitian yang mengungkap tentang kehidupan selebritis yang memiliki latar belakang sebagai duta pariwisata Jakarta atau Abang None Jakarta.

\section{Tradisi}

\section{Sosiopsikologis}

Tradisi dalam sosiopsikologis dapat dibagi menjadi tiga cabang besar: perilaku, kognitif, biologis. Dalam sudut pandang perilaku, teori-teori berkonsetrasi pada bagaimana manusia berperilaku dalam situasi-situasi komunikasi. Teoriteori tersebut biasanya melihat hubungan antara perilaku komunikasi-apa yang kita katakan dan lakukan-dalam kaitannya dengan beberapa variabel, seperti sifat 
pribadi, perbedaan situasi dan pemberalajaran. Yang kedua adalah teori kognitif yang cukup banyak digandrungi saat ini. Cabang ini berkonsentrasi pada bagaimana individu memperoleh, menyimpan dan memproses informasi dalam cara yang mengarahkan output perilaku. Dengan kata lain, apa yang kita lakukan dalam situasi komunikasi bergantung tidak hanya pada bentuk stimulus-respon melainkan pada operasi mental yang digunakan untuk mengelola informasi.

Variasi yang ketiga adalah dari sudut pandang biologis. Karena kajian genetik diasumsikan semakin penting, para ahli psikologi dan teori perilaku pun tertarik dalam efek-efek fungsi dan struktur otak dan faktor genetik dalam menjelaskan perilaku manusia. Para ahli tersebut percaya bahwa banyak dari sifat, cara berpikir, dan perilaku inividu diikat secara biologis dan didapat bukan hanya dari pembelajaran atau faktor-faktor situasi, melainkan oleh pengaruh pengaruh neourobiologis sejak lahir (Littlejohn, 2009:63-65).

\section{Komunikasi Pemasaran Personal}

- Prisgunanto (2006:8), komunikasi pemasaran adalah semua-semua elemen promosi dari marketing mix yang melibatkan komunikasi antar organisasi dan target audience pada segala bentuknya dan ditujukan untuk performance pemasaran.

- Terence A. Shimp (2003), komunikasi pemasaran adalah sarana dimana perusahaan berusaha menginformasikan, membujuk, dan mengingatkan konsumen secara langsung ataupun tidak langsung, tentang produk dan merek yang dijual.

Dari serangkaian pengertian komunikasi pemasaran di atas, peneliti hendak menggabungkan istilah tersebut dengan konsep personal, sehingga menjadi komunikasi pemasaran personal. Hal ini dilandaskan oleh konsep komunikasi pemasaran yang kini kajiannya tidak lagi hanya untuk bidang barang atau jasa saja, melainkan juga digunakan untuk mengkaji manusia/personal. Dewasa ini, yang dipasarkan tidak hanya produk atau jasa, tetapi juga diri, karena diri sebenarnya juga adalah produk. Sehingga dapat peneliti simpulkan bahwa komunikasi pemasaran personal adalah sebuah bentuk sarana komunikasi yang digunakan untuk menginformasikan, membujuk, dan mengingatkan khalayak, baik secara langsung maupun tidak langsung, mengenai citra, atau kredibilitas seseorang/personal.

\section{Personal Branding}

\section{- Brand}

American Marketing Association, mendefinisikan merek atau Brand adalah istilah, tanda, simbol, atau rancangan, atau kombinasi hal-hal tersebut, yang dimaksudkan untuk mengidentifikasi barang atau jasa dari seorang atau sekelompok penjual dan untuk membedakannya dari produk pesaing (Kotler, 2012:215).

Hermawan Kartajaya sebagai Marketing Icon of Indonesia, mendefinisikan merek sebagai indikator nilai yang ditawarkan kepada pelanggan dan atau aset yag menciptakan value bagi pelanggan dengan memperkuat loyalitasnya. (Kartajaya, 2004:11).

- Pengertian Personal Branding

- Personal branding dikatakan sebagai proses di mana orangorang dan karir mereka ditandai sebagai merek. Personal branding merupakan proses dimana seseorang dipandang sebagai sebuah brand (merek) oleh target market (Lair, Sullivan, dan Cheney, 2005:35).

- Personal brand adalah identitas pribadi individu yang mampu menciptakan respon emosional orang lain terhadap kualitas dan nilai yang dimiliki individu tersebut (O'Brien T. , 2007). Tidak hanya itu, personal branding tidak 
bisa sebatas mengkomunikasikan, tetapi juga terlebih dahulu harus mengidentifikasi hal unik, relevan, dan menarik dari individu sehingga dapat meningkatkan karir atau bisnis individu tersebut (Rampersad, 2009; Schawbel, 2015).

\section{Delapan Hukum Personal Branding} Montoya melihat semua contohnya melalui delapan 'hukum' ini (Peter Montoya, 2002).

1. Hukum Spesialisasi (The Law of Specialization)

Montoya menyebut bahwa merek biasanya dibangun di atas satu bidang spesialisasi. Penting untuk menjaga agar merek tetap sederhana, dan menghindari diversifikasi agar menjadi lebih baik pada kegiatan inti.

2. Hukum Kepemimpinan (The Law of Leadership)

Menurut Montoya, pada dasarnya orang ingin dipengaruhi. Mereka menginginkan sosok pemimpin, yakni seseorang yang dapat menghilangkan rasa ketidakpastian dan menawarkan mereka kejelasan.

3. Hukum Kepribadian (The Law of Personality)

Personal branding yang baik menggambarkan kepribadian individu dalam segala aspek, artinya bukan hanya kelebihan atau kesempurnaan, tetapi juga ketidaksempurnaan individu tersebut karena orang lain justru menyukai sosok yang apa adanya, yaitu yang memiliki kelemahan seperti selayaknya seorang manusia.

4. Hukum Perbedaan (The Law of Distinctiveness)

Sebuah personal brand yang efektif perlu memiliki kesan yang kuat dengan menjadi berbeda dari orang lain di dalam bidang atau bisnis yang sama.

5. Hukum Kenampakan (The Law of

Visibility)

Untuk menjadi sukses, personal brand harus terlihat secara konsisten atau terus-menerus hingga personal brand orang tersebut dikenal.

6. Hukum Kesatuan (The Law of Unity) Realita kehidupan pribadi seseorang harus sejalan dengan nilai dan perilaku yang telah ditentukan dari personal brand yang dibangun.

7. Hukum Keteguhan (The Law of

Persistence)

Karena membentuk personal brand memerlukan waktu yang lama, individu harus memiliki keteguhan terhadap personal brand awal yang telah dibentuk, tanpa ragu atau ingin mengubahnya.

8. Hukum Maksud baik (The Law of

\section{Goodwill)}

Pengaruh sebuah personal brand akan lebih besar apabila individu tersebut dipersepsikan secara positif.

\section{Teori Manajemen Privasi Komunikasi}

Teori Manajemen Privasi

Komunikasi dikembangkan oleh Sandra Petronio (2002). Ia menyatakan bahwa CPM adalah teori praktis yang didesain untuk menjelaskan isu-isu "keseharian" seperti yang digambarkan dalam kegiatan kita sehari-hari. Ketika kita bertemu dengan berbagai macam orang dalam kehidupan kita seperti rekan sekerja, teman sekelas, anggota keluarga, teman sekamar, dan seterusnya, kita terlibat di dalam negosiasi kompleks antara privasi dan keterbukaan. Memutuskan apa yang akan diungkapkan dan apa yang harus dirahasiakan bukanlah keputusan yang dapat langsung diambil, melainkan merupakan tindakan penyeimbangan yang berlangsung secara terus-menerus. Kita berusaha untuk menimbang tuntutantuntutan situasi dengan kebutuhan kita dan orang lain yang ada disekitar kita.

\section{Asumsi Dasar CPM}

- Informasi Privat

Asumsi yang pertama, informasi privat merujuk pada cara tradisional untuk berpikir mengenai pembukaan. Ini merupakan informasi mengenai hal-hal yang sangat berarti bagi seseorang 
yang sifatnya privat. Isi dari pembukaan memungkinkan kita untuk menguraikan konsep-konsep mengenai privasi dan keintiman dan mempelajari bagaimana mereka saling berhubungan.

- Batasan Privat

Asumsi yang kedua adalah batasan privat (private boundaries). CPM bergantung pada metafora batasan untuk menjelaskan bahwa terdapat garis antara bersikap publik dan bersikap privat.

- Kontrol dan Kepemilikan

Asumsi yang ketiga berkaitan dengan kontrol dan kepemilikan. Asumsi ini bergantung pada ide bahwa orang merasa mereka memiliki informasi privat mengenai diri mereka sendiri.

- Sistem Manajemen Berdasarkan Aturan Asumsi yang keempat dari teori CPM adalah sistem manajemen berdasarkan aturan. Sistem ini adalah kerangka untuk memahami keputusan yang dibuat orang mengenai informasi privat.

- Dialektika Manajemen

Asumsi yang kelima, dialektika manajemen privasi, berfokus pada ketegangan-ketegangan antara keinginan untuk mengungkapkan informasi privat dan keinginan untuk menutupinya.

\section{Media Sosial}

\section{Pengertian Media Sosial}

Menurut Heidi Cohen dalam buku Komunikasi Antarpersonal (2015:288-289) definisi media sosial terus berubah, berkembang seiring dengan perkembangan penggunaan media sosial itu sendiri. Mengingat begitu dinamisnya deifinisi media sosial, maka Cohen memberikan beberapa pengertian media sosial menurut para ahli yaitu sebagai berikut:

Media sosial adalah media yang tidak berbicara tentang apa yang orang lakukan atau orang katakan tetapi tentang apa yang orang lakukan dan katakan "bersama-sama" tentang sesuatu di dunia dan dipertukarkan di seluruh dunia atau media yang dapat mengkomunikasikan sesuatu pada saat yang sama ke segala arah karena dukungan oleh teknologi digital. (Michele Chmielewski).

\section{Fungsi Media Sosial}

Menurut Jan H. Kietzmann dalam buku Komunikasi Antarpersonal (2015:292-293) fungsi media sosial itu ibarat sarang lebah yang membentuk kerangkan jaringan dari blok-blok yang berhubungan satu sama lain, sebagai berikut.

- Identitas, sebagai sebuah blok dari media sosial yang merinci bagaimana pengguna mengungkapkan identitas diri di tengah- tengah koneksi dengan pengguna lain.

- Conversations, blok yang berisi aktivitas pengguna berkomunikasi dengan pengguna lain. Banyak situs media sosial yang dirancang untuk memfasilitasi percakapan antarpersonal maupun antara personal dengan kelompok atau komunitas lain. Dalam percakapan inilah para pengguna dapat mendapatkan kawan baru, membangun harga diri, menemukan cinta, menyajikan ide baru atau mendorong diskusi yang sedang hangat dibicarakan masyarakat.

- Sharing, media sosial membantu pengguna untuk sharing seperti distribusi pesan, menerima pesan dan bertukar pesan. Bahkan lebih penting dari itu di mana para pengguna melakukan sharing atau pesan untuk mendapatkan konten dalam makna bersama, karena itu istilah sosial dalam media sosial selalu diisiratkan sebagai pertukaran pesan antara manusia secara online.

- Relationship, hubungan menunjukkan sejauh mana pengguna dapat berhubungan dengan pengguna lain.

- Reputation, menunjukkan sejauh mana pengguna dapat mengidentifikasi status sosial orang lain termasuk menyarakan status diri masing-masing. 


\section{Instagram}

Intagram merupakan situs jejaring sosial yang sangat populer untuk mempublikasikan foto. Pengguna menggunggah fotonya secara digital dan menyebarkan fotonya dengan pengguna lain. Instagram telah menjadi pelopor aplikasi penyebaran foto untuk pengguna seluler dan telah memiliki lebih dari 200 juta pengguna.

Cara kerja Instagram adalah setelah pengguna mengunggah fotonya, pengguna bisa menambahkan efek untuk mempercantik foto yang dipublikasikan. Selain itu pengguna bisa menggunakan sistem hashtags untuk mempermudah pengguna lain dengan minat yang sama menemukan foto yang diunggah. (Landsverk, 2014:1)

\section{METODOLOGI PENELITIAN}

\section{Metode Penelitian}

Dalam penelitian ilmiah ada dua macam metode atau pendekatan yang sering digunakan, yaitu kualitatif dan kuantitatif. Untuk mengkaji penelitian ini, penulis menggunakan metode kualitatif.

\section{Paradigma Post Positivisme}

Menurut Guba (1990:20),

"Postpositivism is best characterized asmodified version of positivism. Having assessed the damage that positivism has occured, postpositivists strunggle to limited that damage as well as to adjust to it. Prediction and control continue to be the aim." Kutipan ini artinya adalah Postpositivisme paling baik dikarakteristikkan sebagai versi positivisme yang dimodifikasi. Setelah menilai adanya kekurangan yang terjadi pada positivisme, postpositivists berjuang untuk membatasi kekurangan itu serta menyesuaikan diri dengan itu. Prediksi dan kontrol terus menjadi tujuan.

\section{Studi Kasus Deskriptif}

Dalam melakukan penelitian ini, peneliti menggunakan pendekatan studi kasus deskriptif, di mana jenis pendekatan ini bertujuan agar bisa terfokus pada suatu kasus tertentu secara cermat sampai tuntas. Kajian ini perlu dilakukan secara tajam terhadap berbagai faktor yang terkait dengan kasus tersebut, sehingga akhirnya akan diperoleh kesimpulan yang akurat (Sutedi, 2009:61).

\section{Periode dan Lokasi Penelitian Periode Penelitian}

Periode pelaksanaan penelitian ini mulai dilakukan pada awal Oktober 2017 sampai April 2018, dengan mengumpulkan semua informasi dan data-data yang diperlukan.

\section{Lokasi Penelitian}

Dalam penelitian ini, lokasi yang menjadi tempat peneliti melakukan penelitian adalah rumah kediaman dari Bangpen di Jakarta Utara, Mpok Maudy di Mal Kota Kasablanka, Non Shabina di Mal Baywalk.

\section{Unit Analisis (Subyek dan Obyek penelitian)}

Unit (satuan) analisis dari penelitian ini adalah Fendi (@bangpen), Maudy Koesnaedi (@maudykoesnaedi), dan Shabian Gianti (@ shabinagia). Ketiga unit analisis ini sama-sama layak dan sesuai dengan kriteria yang peneliti harapkan. Mereka adalah selebritis yang sudah sering tampil di TV Nasional maupun di social media Instagram. Bangpen fokus pada konten komedi berupa video yang kerap diunggah di sosial medianya. Shabina Gianti merupakan salah satu pemeran dalam acara komedi "Ok Jek" yang di tayangkan oleh Net TV. Maudy Koesnaedi merupakan seleb yang terkenal dari film "Si Doel" dan masih eksis di TV hingga sekarang ini. Menurut penulis mereka semua layak untuk menjadi narasumber karena mereka sudah memenuhi syarat sebagai seorang selebritis, dan merupakan alumni Abang None Jakarta. Pemilihan sampel dilakukan secara sengaja, guna mendapatkan informasi yang sesuai dengan 
permasalahan penelitian, dimana terlebih dahulu peneliti menetapkan informannya kemudian baru menetapkan alur kerja yang sesuai dengan tema penelitian (Moleong, 2014: 223).

\section{Teknik Pengumpulan Data}

- Observasi berasal dari kata observation yang berarti pengamatan. Metode observasi dilakukan dengan cara mengamati perilaku, kejadian atau kegiatan orang atau sekelompok orang yang diteliti. kemudian mencatat hasil pengamatan tersebut untuk mengetahui apa yang sebenarnya terjadi.

- Wawancara merupakan percakapan dengan maksud tertentu, dan didalamnya terdapat dua pihak yaitu pewawancara yang mengajukan pertanyaan dan terwawancara yang memberikan jawaban atas pertanyaan itu. Dalam penelitian ini, penulis menggunakan metode wawancara mendalam (Depth-Interview), yang secara umum adalah proses memperoleh keterangan untuk tujuan penelitian dengan cara tanya jawab sambil bertatap muka antara pewawancara dan informan dengan atau tanpa pedoman wawancara.

- Analisis Dokumen diartikan sebagai suatu catatan tertulis / gambar yang tersimpan tentang sesuatu yang sudah terjadi. Dokumen merupakan fakta dan data tersimpan dalam berbagai bahan yang berbentuk dokumentasi.

\section{HASIL DAN PEMBAHASAN}

Berdasarkan hasil analisis yang telah peneliti lakukan pada sub bab sebelumnya, maka pada sub bab ini, peneliti akan mencoba melakukan pembahasan hasil dari ketiga subjek penellitian ini yaitu Maundy Koesnaedi, Bangpen, dan Shabina Gianti, sebagai berikut:

\section{Pembahasan Delapan Hukum Personal Branding}

- Hukum Spesialisasi (The Law Of Specialization)

Mereka memahami spesialisasi yang ada dalam diri mereka masing-masing. Hal ini lah yang membuat mereka berhasil mewujudkan personal branding yang mereka inginkan, di wilayah publik. Bangpen memiliki kemampuan dalam berekspresi yang unik disetiap konten komedi yang ia unggah. Mpok Maudy yang sudah menjadi seorang selebritis sejak tahun 1994, ternyata lebih memilih menjadi sosok yang sederhana dan apa adanya. Hal inilah yang menurutnya disukai banyak orang, dan menjadi nilai lebih dalam dirinya. Non Shabi yang merupakan wanita yang berpendidikan, dengan passion yang kuat, dan konsistensi yang tinggi terhadap bidang yang ia tekuni.

- Hukum Kepemimpinan (The Law Of Leadership)

Pada aspek ini, peneliti melihat bahwa ketiga subjek penelitian telah berhasil menjadi sosok panutan yang mampu memotivasi orang lain lewat karya mereka masing-masing. Bangpen dengan karya konten komedinya, sukses membuatnya memiliki followers hingga $371 \mathrm{~K}$. Hal ini membuat orang lain disekitarnya menjadi termotivasi untuk berkarya di media sosial agar bisa seperti dia. Mpok Maudy yang telah lama menjadi selebritis dan memiliki fans yang banyak, mampu memotivasi para fansnya untuk menyukai kesenian Indonesia, dan juga selalu hidup sehat. Non Shabi dengan kegigihannya dalam berusaha, dan mencintai passionnya, sukses membuatnya menjadi pemain sinetron. Hal ini tentu memotivasi orang disekitarnya, agar mau berkarya sesuai passion masing- masing, dan selalu konsisten dalam mengerjakan segala sesuatu. 
- Hukum Kepribadian (The Law Of Personality)

Dengan segala kelebihan yang mereka coba tunjukkan ke hadapan publik, ternyata mereka pun mengakui bahwa mereka juga memiliki kekurangan yang sebetulnya dapat mempengaruhi proses personal branding mereka. Bangpen mengaku bahwa ia memiliki kendala di waktu sehingga hal ini membuatnya tidak bisa secara intens melakukan postingan di instagram. Mpok Maudy mengaku bahwa ia adalah tipe orang yang cukup emosional. Ia belum bisa bersikap cuek terhadap masalah-masalah sepele yang ia temui di instagramnya. Hal ini membuatnya menjadi kurang nyaman. Non Shabi mengaku bahwa ia tipe orang yang blak-blakan dalam beropini. Hal ini terkadang ia terapkan dalam postingannya di instagram, sehingga malah justru mendatangkan kritikan dan kesan negatif dari beberapa orang yang merasa tidak nyaman.

- Hukum Perbedaan (The Law Of Distinctiveness)

Pada aspek ini ketiga subjek penelitian memiliki keyakinan yang menarik terkait strategi agar terlihat berbeda dari orang lain. Pada dasarnya mereka sepakat untuk menjadi diri sendiri. Bangpen merasa bahwa ia harus konsisten dengan ekspresi atau mimik wajahnya yang khas, yang telah digemari oleh netizen. Mpok Maudy pada dasarnya tidak pernah berfikir ingin terlihat berbeda dari orang lain, hanya saja ia merasa memiliki minat dan passion yang berbeda dari orang lain. Kesederhanaan yang ia miliki dianggap menjadi suatu hal yang berbeda dari kebanyakan selebritis. Bagi Non Shabi, ia juga tidak pernah ingin terlihat berbeda dari orang lain, karena karakter beliau ialah wanita apa adanya yang tidak terlalu mengikuti arus jaman agar terlihat beda.

\section{Hukum Kenampakan (The Law Of Visibility)}

Pada aspek ini, ketiga subjek penelitian mengaku bahwa mereka cukup konsisten dalam memberikan konten di instagram. Bangpen sendiri konsisten dengan konten komedinya, namun tetap fleksibel dalam menentukan tema, sesuai perkembangan jaman. Ia pun memiliki standar dalam penyajian konten minimal 2-3 konten per minggunya. Mpok Maudy juga cukup konsisten dalam memberikan postingan diinstagramnya. Hal ini ditandai dengan banyaknya netizen yang memperhatikan dan menyukai setiap postingan yang ia buat. Menurut Non Shabi ia cukup konsisten dalam menyajikan konten diinstagram. Ia fokus dengan tujuannya, dan tidak mengikuti arus jaman.

- Hukum Kesatuan (The Law Of Unity)

Pada aspek ini, ketiga subjek penelitian sepakat bahwa personal branding yang mereka coba ungkapkan di instagram sudah cukup selaras dengan karakter mereka pada aslinya. Bangpen mengaku bahwa ia sedari dulu memang memiliki karakter yang humoris, berani beda, dan senang menghibur orang-orang disekitarnya. Begitu juga dengan Mpok Maudy, karakternya yang sederhana dan passion yang ia miliki adalah sesuatu yang nyata ia miliki. Hanya saja beliau mengaku karena ia seorang selebritis, jadi ada beberapa hal yang harus dijaga agar tidak menimbulkan kontroversi. Menurut Non Shabi ia pun sudah bersikap nyata atas dirinya di Instagram. Ia akui bahwa ia memang orang yang apa adanya dan memiliki passion yang tinggi.

- Hukum Keteguhan (The Law Of Persistence)

Dari ketiga subjek penelitian, peneliti mendapatkan jawaban yang menarik, bahwa mereka semua dari sejak awal memiliki instagram belum terlalu menjadikannya sebagai sarana untuk personal branding. Hal ini karena 
adanya keterbatasan informasi perihal fungsi dan cara kerja Instagram. Seiring waktu berjalan, semakin banyaknya informasi yang diterima, dan juga followers yang kian meningkat, mereka pada akhirnya sepakat untuk fokus menjadikan Instagram sebagai sarana personal branding. Bangpen mulai fokus sejak 2016 lalu, sedangkan Mpok Maudy tidak ada info spesifik mengenai kapan mulai fokus, dan Non Shabi sejak empat tahun terakhir ia sudah mulai serius menggunakan Instagram.

- Hukum Maksud Baik (The Law Of Goodwill)

Pada aspek ini, ketiga subjek penelitian sepakat bahwa agar terlihat positif dikalangan netizen, maka mereka harus berhati-hati dalam proses penyajian kontennya. Upaya yang dilakukan ialah menjaga konten yang disebarkan agar bisa diterima oleh seluruh netizen, dan membuat caption yang positif, agar tidak menyinggung atau menimbulkan kontroversi.

\section{Pembahasan Lima Asumsi Dasar Teori CPM}

- Informasi Privat

Pada aspek ini, ketiga subjek penelitian menyadari akan jenis konten apa yang mereka kerap bagikan. Bangpen dalam menyajikan konten baik foto dan video, semuanya harus berunsur komedi. Hal ini karena ia telah menjadi seorang konten kreator komedi, sehingga ia harus konsisten. Mpok Maudy dalam menyajikan konten, kerap menunjukkan aktivitasnya bersama keluarga, karena selain menyukainya, hal ini juga menjadi sumber informasi bagi banyak orang. Kemudian diikuti dengan konten mengenai pekerjaan dan aktivitasnya di dunia seni dan teater. Non Shabi menganggap bahwa apa yang kita posting di Instagram itu haruslah memiliki nilai yang penting untuk dibagikan. Untuk itu ia kerap menyajikan konten yang menggambarkan kesibukannya seperti saat syuting, dll.

- Batasan Privat

Pada aspek ini, ketiga subjek penelitian mengaku sangat memperhatikan privasi mereka. konten yang mereka sajikan adalah konten yang dianggap layak untuk diketahui publik dan tidak akan menimbulkan dampak di ranah privasi mereka. Bangpen yang fokus dengan bidang komedinya, mengaku jarang menunjukkan hal-hal privasi. Sekalipun ada itu juga hal yang bisa dijadikan bahan komedinya. Sesuai pemaparan dari Mpok Maudy, beliau mengaku amat menjaga privasinya. Ia sangat memperhatikan hal-hal yang mengandung informasi tertentu yang bisa menimbulkan ketidak nyamanan baginya dan netizen. Hal yang utama adalah informasi mengenai keluarganya, karena ia tidak ingin keluarganya terlalu terekspos oleh publik dan media yang bisa bisa berdampak negatif pada privasi mereka. Non Shabi juga sangat memperhatikan batasan informasi yang ia berikan ke publik. Menariknya, Non Shabi dulu sempat mendapatkan teror hingga menyebabkan trauma hingga saat ini, akibat ia tidak menjaga informasi tentang dirinya, sehingga publik bisa mengetahui segala informasi tentang dirinya dan keluarga secara detail. Untuk itu sekarang ia hanya membagikan konten yang menurutnya penting untuk diketahui publik.

- Kontrol dan Kepemilikan

Pada aspek ini, ketiga subjek penelitian mengaku sering mengontrol akun instagram mereka, karena mereka tidak menggunakan jasa orang lain, yang artinya mereka kelola sendiri. Perihal adanya akun lain yang men-stalking akun mereka dan memberikan komentar serta Direct Message (DM), mereka mengaku belum merasa terganggu akan hal itu, karena mereka menganggap itu merupakan efek dari akun mereka yang menggunakan mode 
bisnis. Bangpen mengaku belum pernah memblokir akun orang lain, karena sejauh ini mereka yang bermasalah, masih bisa ditegur. Lain hal dengan Mpok Maudy dan Non Shabi. Mereka berdua pernah memblokir akun orang yang mereka anggap sudah melewati batas, sangat mengganggu privasi, dan tidak bisa ditegur. Untuk Bangpen dan Mpok Maudy, mereka mengaku tidak terlalu sering memperhatikan viewers instastory mereka, namun dalam kasus tertentu mereka akan coba lihat seperti saat mengadakan polling, keperluan endorsement, dll. Non Shabi mengaku ia akan memperhatikan viewers instastory-nya, ketika sudah diatas 100 orang. Hal ini karena ia menjaga privasinya, dan kuatir ada akun asing yang melihatnya. Mereka mengaku cukup memperhatikan akun-akun yang memberi like dan komentar pada postingan mereka. Menurut mereka itu adalah bentuk respon positif dari netizen yang patut untuk diapresiasi dengan memberikan balasan. Pada dasarnya mereka cukup puas dengan sistem keamanan yang disediakan, hanya saja memang perlu untuk terus diawasi dan dikembangkan agar tidak terjadi sesuatu yang tidak diinginkan seperti hack. Mpok Maudy menambahkan, untuk alasan etika, sebaiknya instagram membuat fitur agar orang lain tidak bisa mengambil foto atau video dengan mudah tanpa izin pemiliknya.

- Sistem Manajemen Berdasarkan Aturan Pada aspek ini, ketiga subjek penelitian sepakat bahwa mereka memilih instagram sebagai sarana penunjang personal branding mereka karena pengguna instagram di indonesia yang cukup besar. Dari data yang peneliti coba cari, ternyata pada Januari 2018, Indonesia berada diurutan ketiga sebagai negara pengguna aktif instagram terbesar di dunia, yakni 53 juta pengguna aktif. Selain dari faktor penggunanya, instagram juga dinilai memiliki beraneka ragam fitur yang dapat menunjang kebutuhan penggunanya dalam berkarya, dan yang pasti tampilannya yang menarik dan mudah digunakan. Perihal konten instastory, ketiga subjek penelitian memiliki jawaban masing-masing yang menarik. Bangpen beranggapan dengan ia mengunggah kesehariannya di instastory, maka hal ini bisa membuatnya eksis sekaligus lebih dekat dengan para followers-nya. Selebihnya ia gunakan untuk kepentingan endorsement. Sama dengan Bangpen perihal endorsement, Mpok Maudy kerap membuat instastory untuk keperluan pekerjaanya. Non Shabi mengaku ia tidak terlalu sering membuat instastory karena menurutnya apa yang ia uploud di instastory harus memiliki nilai informasi yang dianggapnya penting. Ketiga subjek penelitian sepakat untuk tidak mengunci akun instagram mereka agar setiap karya yang mereka unggah dapat dilihat dan diapresiasi oleh banyak orang tanpa terkecuali. Ketiga subjek penelitian ternyata pernah mendapat masalah dari postingan yang mereka buat. Kebanyakan masalah ini datang karena mereka kurang berhatihati dalam menyajikan konten, dan menyusun kata-kata di kolom caption. Sejauh ini ketiga subjek penelitian mengaku bahwa mereka belum merasa terganggu dengan adanya spam message dari pengguna lain. Perihal citra yang ingin mereka bangun di instagram, ketiga subjek penelitian memberikan jawaban yang menarik. Bangpen dengan citranya sebagai seorang konten kreator komedi, Mpok Maudy dengan citranya sebagai seorang wanita karir yang memiliki passion akan kesenian yang tinggi, dan karakter yang apa adanya/sederhana, serta Non Shabi dengan citranya sebagai seorang wanita yang memiliki kesibukan yang jelas, passion yang tinggi, dan apa adanya. 


\section{- Dialektika Manajemen}

Secara garis besar, ketiga subjek penelitian mengaku bahwa dalam menyajikan konten, mereka cukup hati-hati dalam memilih konten yang tepat untuk dibagikan, agar tidak menimbulkan hal yang negatif. Jadi tidak hanya sekedar menyampaikan isi konten, tapi juga harus dapat diterima oleh seluruh netizen. Dalam proses uploud, mereka cukup memperhatikan momen yang dianggap penting atau prime time, supaya konten dapat dilihat secara efektif oleh netizen.

\section{KESIMPULAN DAN SARAN}

\section{Kesimpulan}

Pada bab terakhir ini, peneliti akan mencoba memberikan kesimpulan dan saran dari hasil penelitian yang sudah peneliti paparkan pada bab sebelumnya. Kesimpulan yang akan peneliti paparkan, akan mengacu pada hasil analisis dari delapan hukum personal branding (Peter Montoya), dan teori manajemen privasi komunikasi (Sandra Petronio), terhadap ketiga subjek penelitian yaitu Maudy Koesnaedi, Bangpen, dan Shabina Gianti.

Dari delapan hukum personal branding, peneliti melihat bahwa ketiga subjek penelitian memiliki keistimewaan yang berbeda-beda sesuai passion mereka. Mereka juga mampu memotivasi orangorang disekitarnya lewat karya yang diunggah lewat instagram. Mereka pun menyadari akan kekurangan mereka yang dapat mengganggu proses personal branding.

Ketiga subjek penelitian meyakini, bahwa menjadi diri sendiri adalah cara agar terlihat berbeda dari orang lain. Mereka mengaku cukup konsisten dalam mengelola personal branding mereka di instagram. Personal branding yang mereka tunjukkan di instagram, ternyata cukup selaras dengan karakter mereka pada aslinya. Mereka mengaku, ketika menyadari fungsi dan cara kerja instagram dengan baik, mereka kemudian memiliki keteguhan dalam melakukan proses personal branding. Supaya terlihat positif dikalangan netizen, mereka selalu berupaya menjaga konten yang mereka bagikan agar tidak menyinggung orang lain, dan menggunakan kata-kata yang positif.

Dari kelima asumsi teori manajemen privasi komunikasi yang meliputi informasi privat, batasan privat, kontrol dan kepemilikan, sistem manajemen berdasarkan aturan, dan dialektika manajemen, peneliti dapat menyimpulkan bahwa ketiga subjek penelitian secara garis besar sudah mengetahui batasan privasi mereka dengan publik, sehingga mereka memahami informasi apa yang boleh dan tidak untuk dibagikan kepada publik. Mereka memiliki pengelolaan manajemen yang baik, antara mereka dan netizen.

\section{DAFTAR PUSTAKA}

Adrian, Sutedi. 2009. Metode Penelitian Hukum. Jakarta: Sinar Grafika.

Afirianto, S. 2013. Dinamika Perkembangan Pemanfaatan Teknologi Informasi dan Komunikasi Serta Implikasinya di Masyarakat. Jakarta: Media Bangsa.

Ardianto, Elvinaro dan Bambang QAnees. 2009. Filsafat Ilmu Komunikasi. Bandung: Simbiosa Rekatama Media.

Bungin, Burhan. 2006. Analisis Data Penelitian Kualitatif Pemahaman Filosofis dan Metodologis ke Arah Penguasaan Model Aplikasi. Jakarta: Raja Grafindo Perkasa.

Cohen, Heidi. 2015. Komunikasi Antarpersonal. Jakarta: Prenada Media.

Daniel J. Lair, Katie Sullivan dan George Cheney. 2005. Marketization and The Recasting Of The Professional Self: The Rhetoric and Ethics Of Personal Branding. Utah: Sage Publications. 
Danim, Sudarwan. 2002. Menjadi Peneliti Kualitatif. Bandung: Pustaka Setia.

Daymon, Christine \& Holloway, Immy. 2008. Riset Kualitatif Dalam Public Relations \& Marketing Communicatoins. Yogyakarta: IKAPI.

Erik Deckers, K. L. 2012. Branding Yourself: How to Use Social Media to Invent or Reinvent Yourself. Indianapolis: Que Publishing.

Egon G. 1990. The Paradigm Dialog. California : SAGE Publications, Inc.

Flew, Terry. 2008. New Media: an Introduction. Australia: Oxford University Press.Guba,

Hamidi. 2005. Metode Penelitian Kualitatif. Malang: UMM Press.

Haroen, Dewi. 2014. Personal Branding: Kunci Kesuksesan Berkiprah di Dunia Politik. Jakarta: Erlangga.

Hood, T. 2006. Personal Brandwagon. Ecademy Press.

https://kbbi.web.id/selebriti

https://en.oxforddictionaries.com/definition/ celebrity

http://www.tribunnews.com/seleb/2012/07/ 04/kalau-cuma-jadi-artis-buat-apaikut-kontes-abang-none?page $=2$

http://www.wylvera.com/2015/05/abangnone-jakarta-cerdas-danberbudaya.html

Ilham, Prisgunanto. 2006. Komunikasi Pemasaran. Jakarta: Ghalia Indonesia.

Kartajaya, Hermawan. 2004. Positioning, Diferentiationi, and Brand. Jakarta: PT. Gramedia Pustaka Utama.

Kayode, Olujimi. 2014. Marketing Communications, edisi 1. Bookboon.

Kotler, Philip. 2009. Manajemen Pemasaran, edisi 13. Jakarta: Erlangga.

\section{Manajemen} Pemasaran. Jakarta: Erlangga.

Landsverk, Kjell Halvor. 2014. The Instagram Handbook. London: Primehead Limited.
Littlejohn, Stephen W dan Karen A. Foss. 2009. Teori Komunikasi Theories of Human Communication edisi 9. Jakarta: Salemba Humanika.

McNally, D., \& Speak, K. D. 2012. Be Your Own Brand: Achieve More of What You Want by Being More of Who You Are. San Francisco: BerrettKoehler Publishers.

McQuail, Denis. 2011. Teori Komunikasi Massa Buku 1. Jakarta: Salemba Humanika

Moleong, Lexy J. 2002. Metodologi Penelitian Kualitatif. Bandung: Remaja Rosdakarya.

2010. Metodologi

Penelitian Kualitatif Edisi Revisi. Bandung: Remaja Rosdakarya.

Montoya, Peter. 2002. The Personal Branding Phenomenon. Nashville: Vaughan Printing.

Mulyana, Dedy. 2013. Metodologi Penelitian Kualitatif: Paradigma Baru Ilmu Komunikasi dan Ilmu Sosial Lainnya. Bandung: Remaja Rosdakarya.

Murni, Sylviana. 2011. Pernak-Pernik Abang dan None Jakarta. Jakarta. PT Mahendra Agung Jaya.

O'Brien, T. 2007. Sior Professional Report Archive. Diakses 3 April 2018, dari SIOR:

http://www.sior.com/resources/siorreport/professional-reportarchive/professional-reportarchive-past-print-issues

Patton, Michael Quinn. 1987. Qualitative Education Methods. Beverly Hills: Sage Publication.

Rakhmat, Jalaluddin. 2013. Psikologi Komunikasi. Bandung: Remaja Rosdakarya.

Rampersad, H. K. 2009. Authentic Personal Branding: A New Blueprint for Building and Aligning a Powerful Leadership Brand. Charlotte, NC: Information Age Publishing Inc.

Salim, Agus. 2001. Teori dan Paradigma Penelitian Sosial. Yogyakarta: PT. Tiara Kencana. 
Schawbel, D. Richard West, Lynn H.Turner. 2008. Pengantar Teori Komunikasi: Analisis dan Aplikasi. Buku 1 Edisi 3. Jakarta: Salemba Humanika.

Sedarmayanti dan Hidayat, Syarifudin. 2011. Metodologi Penelitian. Bandung: Mandar Maju.

Shimp, Terence, A. 2003. Periklanan Promosi Aspek Tambahan Komunikasi Terpadu. Terjemahan, Edisi ke-1 jilid 5. Jakarta: Erlangga.
Subur, J. 2011. Employee Revolution. Depok: Penebar Swadaya Group.

Sugiyono. 2006. Metode Penelitian Pendidikan, Pendekatan Kuantitatif, Kualitatif dan $R \& D$. Bandung: Alfabeta.

2009. Metode Penelitian Bisnis Pendekatan Kuantitatif, Kualitatif, dan $R \& D$. Bandung: Alfabeta

Wood, Julia T. 2014. Komunikasi Teori dan Praktik Komunikasi dalam Kehidupan Kita Edisi 6. Jakarta: Salemba Humanika

Yunus, Hadi Sabari. 2010. Metode Penelitian Wilayah Kontemporer. Yogyakarta: Pustaka Pelajar. 